\title{
Characteristics Of Accounting Faculty In The U.S.
}

Ravindra R. Kamath, Cleveland State University, USA

Heidi Hylton Meier, Cleveland State University, USA

Edward G. Thomas, Cleveland State University, USA

\begin{abstract}
In this article, the academic and personal characteristics of Accounting faculty members at Colleges and Universities in the United States are analyzed to determine the demographics of the Accounting Professorate. Data on 12 variables were collected for the 2004-2005 academic year as a means of constructing a professional profile of the typical accounting professor teaching at today's universities. Given that there are anticipated shortages of accounting faculty, this information should be of interest to students who are considering accounting as a major, those contemplating entering the profession, and those faculty members who are engaged in educating the next generation of accounting faculty members.
\end{abstract}

Keywords: Profile of Accounting Faculty in the United States ; Personal Characteristics of Accounting Faculty; Teaching Interests of Accounting Faculty; Research Interests of Accounting Faculty

\section{INTRODUCTION}

$\mathrm{n}$ light of the recent report of the American Accounting Association (AAA), there has been considerable
interest in the expected shortages of accounting faculty that is anticipated in the next few years. According to the AAA study (2008), the number of accounting faculty has decreased by $13.3 \%$ from 1988 to 2004 with the highest decline of $31 \%$ observed at four-year, non-doctoral granting institutions (p. 7). These declines are particularly alarming as for the same time period, enrollment of undergraduate accounting students has increased by $12.3 \%$ and is expected to increase even more in the future (AAA, 2008, p.11). In addition, many of the current accounting faculty are expected to retire in the near future which is expected to create extreme shortages in the accounting departments at many colleges and universities.

This paper examines the accounting professoriate in the academic year 2004-2005 to further investigate the demographic characteristics of these faculty described in the AAA report (2008) which is quite extensive, examining many salary and work load issues that are not addressed in this study. Rather, we focus on the academic and personal characteristics of these faculty to present a profile of the typical accounting faculty member.

\section{LITERATURE REVIEW}

Before the results of the current study are presented, it is appropriate to consider the previous research on this subject. While a considerable body of literature exists on the academic accounting profession, particularly concerning faculty research and publication issues and career advancement topics, a relative handful of studies have been published that concentrate primarily on accounting faculty background variables or profiles. The following review concentrates on some of the most significant of those articles.

Newell and Langsam (1996) compared profiles of accounting doctoral degree holders from 1970, 1980, and 1990 as they attempted to identify changes in the academic environment that these faculty members experienced in their careers. Demographic, behavioral, and attitudinal data were collected via questionnaires. The major findings were that, overall, most doctoral graduates in accounting took academic jobs upon graduation (primarily for lifestyle preferences); most joined schools having graduate programs; most exhibited high levels of satisfaction with their 
career choices; and most had experienced moderate to high levels of stress in their current positions. Newer faculty members were more likely than the others to have non-business undergraduate majors, were older when they received their degrees, and took longer to complete their doctoral programs. They also tended to have fewer certifications, to perceive that stress levels in academia are higher than in the non-academic world, and to place greater emphasis than their counterparts on publication and research.

In a study of the changing characteristics of accounting faculty members, Gibson and Schroeder (1998) gathered data on accounting faculty from 39 New York and New Jersey colleges and universities using two of Hasselback's directories of accounting faculty (Hasselback 1983; Hasselback 1995). Comparing the profiles of faculty from the two time periods, the authors identified the following trends: (1) The number of full-time faculty declined by ten percent; (2) The percentage of accounting faculty holding a doctoral degree increased from 32 percent to 55 percent, with most faculty holding a degree in accounting; (3) The percentage of faculty holding professional certification increased from 62 to 64 percent, with the percentage of Ph.D. faculty holding professional certification increasing from 48 to 52 percent; and (4) There was a significant increase in the number of female accounting faculty members, most of whom hold a doctoral degree.

During the mid- to late-1990s, a number of research articles explored gender issues in the academic accounting profession. Omundson and Mann (1994) looked at the publication productivity of female accounting faculty compared to their male counterparts. They examined the publication records of 679 faculty members who were promoted to professor or associate professor at AACSB-accredited schools from 1983 until 1989. A statistical analysis of the publication records by gender revealed "no significant gender effect among those promoted to either professor or associate professor." They further determined that there was no significant difference between the sexes in the time required to achieve promotion.

Streuly and Maranto (1994) examined accounting faculty research productivity to determine if gender differences existed among those who received accounting doctorates between 1960 and 1986 . Their research analysis revealed that "the majority of women accounting faculty have achieved comparable levels of research quantity, quality, and impact as their male counterparts."

Dwyer (1994) also studied the scholarly activities of accounting faculty to determine if gender differences exist. Using a sample of accounting faculty who had received their doctorates in 1981, Dwyer found that, compared to men, women had fewer total post-doctoral publications overall and fewer publications in academic journals. However, men and women received equivalent numbers of total citations of their work, leading the author to conclude that "although women produce fewer papers than men, the total impact of women's papers is as great as the total impact of men's papers."

Similarly, Rama, Raghunandan, Logan, and Barkman (1997) examined the publication productivity of 281 accounting faculty promoted to the position of associate professor at AACSB-accredited institutions over the sixyear period from 1989 to 1994 . They determined that gender differences did exist in the publication productivity of faculty promoted at non-doctoral institutions, with female faculty having had more publications than their male counterparts at the time of promotion. However, there were no differences detected between the sexes at doctoral institutions.

Focusing on the hiring of female academic accountants, Carolfi and Pillsbury (1996) analyzed data from the 1979 to 1990 Hasselback directories of accounting faculty to identify employment patterns. They found that women had been most successful in joining the faculties at small and medium-sized schools. However, there was "no evidence that women have been excluded from the ranks of the prestigious accounting institutions."

Collins, Reitenga, Collins, and Lane (2000) also studied the effect of gender on the initial employment decision in academic accounting. Using data from Hasselback's accounting faculty directories from 1991 through 1997, the authors found that female candidates from top-tier and bottom-tier doctoral programs were just as likely as male graduates to gain appointments at doctoral-granting institutions while female candidates from middle-tier doctoral programs were less likely than males to obtain positions at doctoral granting schools. The authors were 
unable to determine whether this difference was due to some self-selection phenomenon or to some form of systemic discrimination.

Collins, Parrish, and Collins (1998) examined the relationship between gender and the career advancement of accounting academicians on two measures: application for tenure at the first employment position and achievement of tenure at the first employment position. Using a logit model and controlling for factors that are expected to affect the decision to apply for tenure, they found no differences between male and female faculty members in the likelihood of applying for tenure. Using a subsample of faculty members who actually applied for tenure and controlling for factors that might affect tenure decisions, they "found no gender differences in the award of tenure."

\section{METHODOLOGY}

Data for this study were derived from the 2004-2005 Accounting Faculty Directory edited by Hasselback (2004) which contains information about faculty members in accounting departments at more than 1,000 colleges and universities in the United States and at some international schools. For this study, only faculty members from colleges and universities in the United States, excluding any who have retired or are deceased, were selected.

To select the faculty members in this study, a modified random sampling procedure was used. The Hasselback directory lists faculty members both by institution and alphabetically by name. The alphabetical listing was used to select the random sample for this study using the following procedures. Each page of the alphabetical listing contains approximately 72 names of accounting faculty members. Five faculty members were chosen from each page by taking two from the top of the page, two from the bottom of the page and one from the center of the page. Since only faculty from the U.S. were to be included, if a faculty member from an international school was chosen, the next person listed from a U.S. school was chosen. Using this procedure, a sample of 850 accounting faculty members was selected. In effect, the modified random sample used for this study represents approximately $7 \%$ of the population of accounting professors listed in the Hasselback Directory.

For each faculty member selected, the following data items were derived from the Hasselback directory: academic rank, whether they were serving as an administrator, whether they held a named professorship or endowed chair, highest degree earned, year that they received their highest degree, name of school which granted their highest degree, name of school where they are employed, areas of teaching and research interest, and professional certification(s) that they hold.

The gender of the faculty member was obtained by visual inspection of their name. In cases where the gender was not clear by examining the first name, additional methods were employed such as using their institution's website, or by calling the faculty member or their department to obtain this information. In addition, Carnegie Classification and the Private or Public status of the faculty members' schools was derived from those directories, the Internet and the websites of many of the universities and colleges.

Once the data had been collected, it was tabulated to provide a profile of the current accounting professorate. Our results are then compared to other recent studies regarding characteristics of accounting faculty members and we then draw some conclusions regarding the future of the profession.

\section{RESULTS}

\section{General Characteristics of the Faculty Members}

Table 1 provides general information about the random sample of accounting faculty in 2004-2005. Of the 850 faculty members selected, 590 or $69.4 \%$ were male and 260 or $30.6 \%$ were female. With regard to the rank of these professors, 47.8\% are Full Professors, 30.2\% are Associates Professors, 27.4\% are Assistant Professors, and less than $10 \%$ held other ranks of Instructor, Lecturer, Visiting Professor or Term Faculty. 
Table 1: Academic Rank held by Accounting Professors

\begin{tabular}{|l|c|c|c|c|c|c|}
\hline & \multicolumn{2}{|c|}{ Total } & \multicolumn{2}{c|}{ Men } & \multicolumn{2}{c|}{ Women } \\
\hline Academic Rank & Number & Percentage & Number & Percentage & Number & Percentage \\
\hline Full & 282 & $47.8 \%$ & 240 & $40.7 \%$ & 42 & $16.2 \%$ \\
\hline Associate & 257 & $30.2 \%$ & 179 & $30.3 \%$ & 78 & $30.0 \%$ \\
\hline Assistant & 233 & $27.4 \%$ & 125 & $21.2 \%$ & 108 & $41.5 \%$ \\
\hline Other & 78 & $9.2 \%$ & 46 & $7.8 \%$ & 32 & $12.3 \%$ \\
\hline Total & 850 & $100.0 \%$ & 590 & $100.0 \%$ & 260 & $100.0 \%$ \\
\hline
\end{tabular}

When looking at these percentages, those for women are slightly higher than reported by the American Assembly of Collegiate Business Schools International (AACSB) when in 1999-2000 they reported that 23.3\% of all business faculty were women. However, when looking at the rank held by these professors, there are differences, especially in the proportions of Full Professors as only 42 or $14.9 \%$ of all Full Professors of Accounting are women, whereas 240 or $85.1 \%$ of all Full Professors are men. Moving through the other ranks, the percentages for Associate Professors and Assistant Professors begin to become more evenly distributed.

Table 2: Highest Degree Earned by Accounting Professors

\begin{tabular}{|l|c|c|c|c|c|c|}
\hline & \multicolumn{2}{|c|}{ Total } & \multicolumn{2}{c|}{ Men } & \multicolumn{2}{c|}{ Women } \\
\hline \multicolumn{1}{|c|}{ Academic Degree } & Number & Percentage & Number & Percentage & Number & Percentage \\
\hline & & & & & & \\
\hline Ph D or Equivalent & 684 & $80.5 \%$ & 486 & $82.4 \%$ & 198 & $76.2 \%$ \\
\hline Master's & 163 & $19.1 \%$ & 102 & $17.3 \%$ & 61 & $23.5 \%$ \\
\hline Others & 3 & $0.4 \%$. & 2 & $0.3 \%$ & 1 & $0.3 \%$ \\
\hline Total & 850 & $100.0 \%$ & 590 & $100.0 \%$ & 260 & $100.0 \%$ \\
\hline
\end{tabular}

In Table 2, the Highest Degree earned by accounting faculty members is presented. Those faculty with a Ph.D. degree or the equivalent comprised $80.5 \%$ of the total sample while those with a Master's degree were $19.1 \%$. Very few, less than one percent, held a degree less than a Master's. When examining these percentages by gender, the percentages are very close, providing only a slight difference in the percentages of Master's degree holders, where slightly more women have a Master's degree as their highest degree.

Table 3: Year that Accounting Professors Received their Highest Degrees

\begin{tabular}{|l|c|c|c|c|c|c|}
\hline & \multicolumn{2}{|c|}{ Total } & \multicolumn{2}{c|}{ Men } & \multicolumn{2}{c|}{ Women } \\
\hline & Number & Percentage & Number & Percentage & Number & Percentage \\
\hline & & & & & & \\
\hline 1959 and Before & 3 & $0.3 \%$ & 3 & $1.5 \%$ & 0 & $0.0 \%$ \\
\hline $1960-1969$ & 35 & $4.1 \%$ & 33 & $5.6 \%$ & 2 & $0.8 \%$ \\
\hline $1970-1979$ & 193 & $22.7 \%$ & 165 & $28.0 \%$ & 28 & $10.8 \%$ \\
\hline $1980-1989$ & 263 & $30.9 \%$ & 190 & $32.2 \%$ & 73 & $28.1 \%$ \\
\hline $1990-1999$ & 252 & $29.6 \%$ & 143 & $24.2 \%$ & 109 & $41.9 \%$ \\
\hline 2000 and After & 72 & $8.5 \%$ & 33 & $5.6 \%$ & 39 & $15.0 \%$ \\
\hline Not Available & 32 & $3.8 \%$ & 23 & $3.9 \%$ & 9 & $3.5 \%$ \\
\hline Total Number of Professors & 850 & $100 \%$ & 590 & $100 \%$ & 260 & $100 \%$ \\
\hline
\end{tabular}

It is also interesting to note when these accounting faculty received their highest degrees. Table 3 provides this information. As noted in this table, the largest percentage of Accounting Faculty received their highest degrees in the 1980 - 1989 decade, followed closely by the 1990 - 1999 decade. The mean graduation date for this sample of accounting faculty is 1983 which means that most of these faculty members have been employed in the 
professoriate for at least 25 years. This observation is consistent with the study by the AAA (2008) which states that the mean age of accounting faculty is increasing and that the retirement rate is increasing, as well (p. 32).

Table 3 also provides a breakdown of the number and percentages of the year the highest degree was earned by gender. There was a large influx of women into the professoriate during the 1980's and that for the few years after 2000 included in this study, more women than men were granted their highest degrees. These results are in agreement with Gibson and Schroeder (1998) as they also noted that there has been a significant increase in the number of women into the accounting professoriate. The AAA study notes that although the number of women coming into the profession has not increased significantly, women are becoming a larger proportion of the total faculty because the number of male faculty members is decreasing (p.32).

With regard to accounting faculty, an important characteristic is whether the individual holds a professional certification, of which there are several in accounting. According to Table 4, more than $64 \%$ of all accounting faculty held the designation of Certified Public Accountant (CPA) while less than $15 \%$ have chosen one of the other major certifications. Only a few $(8.1 \%)$ of the faculty members have received more than one professional certification. If we were to examine these percentages along gender lines, we would find that only $29.2 \%$ of women accounting faculty hold the CPA certification. This lower percentage of women holding certifications provides additional evidence to the conclusions stated by Newell and Langsom (1996).

Table 4: Professional Certification held by Accounting Professors

\begin{tabular}{|l|c|c|}
\hline & Number & Percentage \\
\hline & & $64.7 \%$ \\
\hline Certified Public Accountant (CPA) & 550 & $10.8 \%$ \\
\hline Certified Management Accountant (CMA) & 92 & $3.1 \%$ \\
\hline Certified Internal Auditor (CIA) & 26 & $1.2 \%$ \\
\hline All three (CPA, CMA and CIA) & 10 & $6.9 \%$ \\
\hline Two Certifications & 59 & \\
\hline
\end{tabular}

In some cases, faculty members hold positions as named professors or endowed chairs as a reward for their research or teaching accomplishments. In particular, there are many named professorships in the discipline of accounting, a number which exceeded 500 in the 2002-2003 academic year (Meier and Kamath, 2005). Of the accounting faculty included in this study, Table 5 reveals that 96 or $11.3 \%$ of the sample were holders of one of these named professorships.

Table 5: Accounting Professors who are also Named Professors or Administrators

\begin{tabular}{|l|c|c|}
\hline & Number & Percentage \\
\hline & & $11.3 \%$ \\
\hline Named Professor & 96 & $88.7 \%$ \\
\hline Not Named Professor & 754 & $100.0 \%$ \\
\hline Total & 850 & $9.8 \%$ \\
\hline & & $90.2 \%$ \\
\hline Administrator & 83 & $100.0 \%$ \\
\hline Not Administrator & 767 & \\
\hline Total & 850 & \\
\hline
\end{tabular}

Also in Table 5 is information about the number of accounting faculty who hold an administrative position in addition to their faculty role, like Chair, Associate Dean, Dean or Director. In 2004-2005, nearly $10 \%$ of all accounting faculty had these additional responsibilities. Of the 96 named professors and 83 administrators, women hold $13(13.5 \%)$ and $21(25.3 \%)$ of these positions. 


\section{Teaching and Research Interests of Faculty Members}

In Table 6, information regarding the teaching and research interests of the accounting faculty are presented. Hasselback uses 26 different categories from which professors can choose to describe their areas of expertise. Of the 850 faculty members, 833 or $98 \%$ provided areas of interest, but because faculty can use more than one category, the number of preferences adds up to more than the 850 faculty members included in the sample. When examining the data in this table, it can be seen that Financial Accounting is the most cited area, with more than $60 \%$, of all faculty claiming Financial Accounting as one of their main areas of interest for teaching and research. Looking at the other areas, the second most cited area of interest is Managerial Accounting with more than $33 \%$, the third is Auditing with 28.5\%, the fourth is Tax with $18.6 \%$ and fifth is Accounting Systems with 14.4\% of the faculty claiming these areas.

Table 6: Teaching and Research Interests of Accounting Faculty

\begin{tabular}{|c|c|c|c|}
\hline & Area of Expertise & Number & Rank \\
\hline A & Auditing & 241 & 3 \\
\hline $\mathrm{B}$ & Behavioral & 55 & 11 \\
\hline $\mathrm{C}$ & Cost Accounting & 113 & 6 \\
\hline $\mathrm{D}$ & Computer & 24 & 16 \\
\hline $\mathrm{E}$ & Accounting Education & 25 & 15 \\
\hline $\mathrm{F}$ & Financial Accounting & 513 & 1 \\
\hline $\mathrm{G}$ & Governmental Accounting & 44 & 12 \\
\hline $\mathrm{H}$ & Accounting History & 7 & 21 \\
\hline I & International Accounting & 68 & 8 \\
\hline $\mathrm{J}$ & Ethics & 23 & 17 \\
\hline $\mathrm{K}$ & SEC & 5 & 24 \\
\hline $\mathrm{L}$ & Business Law & 36 & 13 \\
\hline $\mathrm{M}$ & Managerial Accounting & 285 & 2 \\
\hline $\mathrm{N}$ & Not-for-Profit & 24 & 14 \\
\hline $\mathrm{O}$ & Internal Auditing & 13 & 19 \\
\hline $\mathrm{P}$ & Principles of Accounting & 83 & 7 \\
\hline Q & Quantitative & 11 & 22 \\
\hline $\mathrm{R}$ & CPA Review & 15 & 18 \\
\hline$S$ & Accounting Systems & 122 & 5 \\
\hline $\mathrm{T}$ & Accounting Theory & 62 & 10 \\
\hline $\mathrm{U}$ & Controllership & 6 & 22 \\
\hline $\mathrm{V}$ & Advanced Accounting & 66 & 9 \\
\hline $\mathrm{W}$ & Social & 6 & 23 \\
\hline $\mathrm{X}$ & Tax & 158 & 4 \\
\hline $\mathrm{Y}$ & Agency & 3 & 25 \\
\hline \multirow[t]{2}{*}{$\mathrm{Z}$} & Oil and Gas Accounting & 1 & 26 \\
\hline & Not Available & 17 & N/A \\
\hline
\end{tabular}

\section{Characteristics of the Institutions}

In addition to developing a profile of the accounting faculty members, we also examined some of the characteristics of the institutions where the accounting faculty are currently teaching and where they received their highest degrees. Two of the factors that were examined were whether these institutions were State or Private in nature and their Carnegie Classification. In 2004-2005, more than 64\% of the accounting faculty in our sample were teaching at State institutions. Of those same faculty members, more than $72 \%$ had received their highest degree from a State institution. 
Related to the type of institution is their Carnegie Classification. The Carnegie Classification is a system of classifying institutions based on their primary mission or their orientation toward teaching and research, the number and level of degrees granted and the amount of federally funded grants that the institution receives. In 2004-2005, more than $34 \%$ of the accounting faculty were teaching at schools that had a Carnegie Classification of 1, or a Doctoral/Research University-Extensive and nearly $15 \%$ were at a school with a Carnegie Classification of 2, or a Doctoral/Research University-Intensive. However, it was institutions with a Carnegie Classification of 3, Masters' Colleges and Universities I, that had the largest concentration of the accounting faculty in our study with more than $39 \%$ of them teaching there.

With regard to the Carnegie Classifications of the institutions where the accounting faculty received their highest degrees, more than $81 \%$ received their highest degree from an institution with a Carnegie Classification of 1 , Doctoral/Research University-Extensive. Only $55(6.5 \%)$ and $68(8 \%)$ received their degrees from an institution with a Carnegie Classification of 2 (Doctoral/Research University-Intensive) and Carnegie Classification of 3 (Masters' Colleges and Universities I), respectively.

\section{CONCLUSION}

This study was designed to provide a profile of the general characteristics of the typical accounting faculty member in the 2004-2005 academic year. Data on 12 variables were collected for the 850 faculty members randomly selected in this study. Based on these variables, the attributes of the faculty members yield the following profile: The typical accounting faculty member is male, holds a Ph.D degree granted from a State Institution with a Carnegie Classification of 1 and most likely received that degree between 1980 and 1989. In addition, this individual most likely is a CPA, teaches and performs research in the area of Financial Accounting, most likely at a State University with a Carnegie Classification of a 1, 2, or 3 and has been in the professoriate for approximately 25 years.

The results of this study provide additional evidence to the AAA study (2008) on the current status of accounting faculty in the U.S. Based on their study, the production of accounting faculty (the number of new Ph.D.s entering academe) falls very short of the number of current faculty retiring. They estimate that demand for new accounting faculty will be approximately 500 new members for the next $5-10$ years whereas the supply is about 140 new members per year (of which one-half are foreign nationals) (AAA, p. 32). This gap between the demand and supply for accounting faculty will create a shortfall that may have a severe impact on accounting education in the U.S. Accounting faculty are already facing increased workloads and pressure to perform academic research. The hope is that given these additional constraints, the quality of academic accounting programs will not be negatively affected.

\section{AUTHOR INFORMATION}

Dr. Ravindra R. Kamath earned his Ph.D. degree in finance at the University of Cincinnati in 1976. He currently is a professor of finance at Cleveland State University . In addition to being the author or co-author of numerous scholarly journal articles and conference presentations, Dr. Kamath has won awards for teaching, research, and service, both at his current institution and internationally.

Heidi Hylton Meier, Professor of Accounting, has been a member of the Cleveland State University faculty since 1986. She received her DBA from Kent State University and is a licensed CPA in the state of Ohio. She has served in several administrative capacities during her tenure at CSU, and teaches courses in the areas of managerial and financial accounting, and auditing. Her research has been published in many adacemic and professional journals and has conducted seminars for both private and professional organizations.

Edward G. Thomas is Professor Emeritus of Marketing in the Nance College of Buisness Administration at Cleveland State University, which he joined as an assistant professor in 1973. His doctorate is from the University of Kentucky. His research interests are in the areas of services marketing, marketing strategy, cross-cultural marketing, and business ethics. His articles have appeared in numerous journals in the marketing and business education fields. In addition to his academic duties at CSU, he served for almost 20 years in a number of 
administrative positions in the business college, including department chair, assistant dean, associate dean, and interim dean.

\section{SOURCES}

1. AASCB International. (2001). Closing the Gender Gap. Newsline (Spring). Retrieved from http://www.aacsb.edu, July 14, 2005.

2. American Accounting Association. (2008). Accounting Faculty in U.S. Colleges and Universities: Status and Trends, $1993-2004$.

3. Carolfi, Iris A., and Ceil Moran Pillsbury. (1996). The Hiring of Women in Accounting Academia. Journal of Education for Business, Vol. 71, No. 3: 151-156.

4. Collins, Allison B., Barbara Parrish, and Denton L. Collins. (1998). Gender and the Tenure Track: Some Survey Evidence. Issues in Accounting Education, Vol. 13, No. 2: 277-299.

5. Collins, Denton L., Austin Reitenga, Allison B. Collins, and Scott Lane. (2000). "Glass Walls" in Academic Accounting? The Role of Gender in Initial Employment Position. Issues in Accounting Education, Vol. 15, No. 3: 372-392.

6. Dwyer, Peggy D. (1994). Gender Differences in the Scholarly Activities of Accounting Academics: An Empirical Investigation. Issue in Accounting Education, Vol. 9, No. 2: 231-246.

7. Gibson, Charles, and Nicholas Schroeder. (1998). The Changing Face of Accounting Faculties. Review of Business, Vol. 19, No. 2: 16-20.

8. Hasselback, James R. (1983). 1982-83 Accounting Faculty Directory. Upper Saddle River, NJ: PrenticeHall.

9. Hasselback, James R. (1995). 1994-95 Accounting Faculty Directory. Upper Saddle River, NJ: PrenticeHall.

10. Hasselback, James R. (2004). 2004-2005 Accounting Faculty Directory. Upper Saddle River, NJ: Prentice-Hall.

11. Meier, Heidi H. and Ravindra Kamath (2005). A Multidimensional Investigation of Named Professorships in Accounting: 2002-2003. Journal of Education for Business. Vol. 80 No. 5.

12. Newell, Gale, and Sheldon Langsam. (1996). Accounting Faculty Profiles: Demographics and Perceptions of Academia. Journal of Education for Business, Vol. 72, No. 2: 87-93.

13. Omundson, Janet S., and Gary J. Mann. (1994). Publication Productivity and Promotion of Accounting Faculty Women: A Comparative Study. Journal of Education for Business, Vol. 70, No. 1: 17-24.

14. Rama, Dasaratha V., K. Raghunandan, Lawrence B. Logan, and Beryl Barkman. (1997). Gender Differences in Publications by Promoted Faculty. Issues in Accounting Education, Vol. 12, No. 2: 353-365.

15. Streuly, Carolyn A., and Cheryl L. Maranto. (1994). Accounting Faculty Research Productivity and Citations: Are there Gender Differences? Issues in Accounting Education, Vol. 9, No. 2: 247-258. 